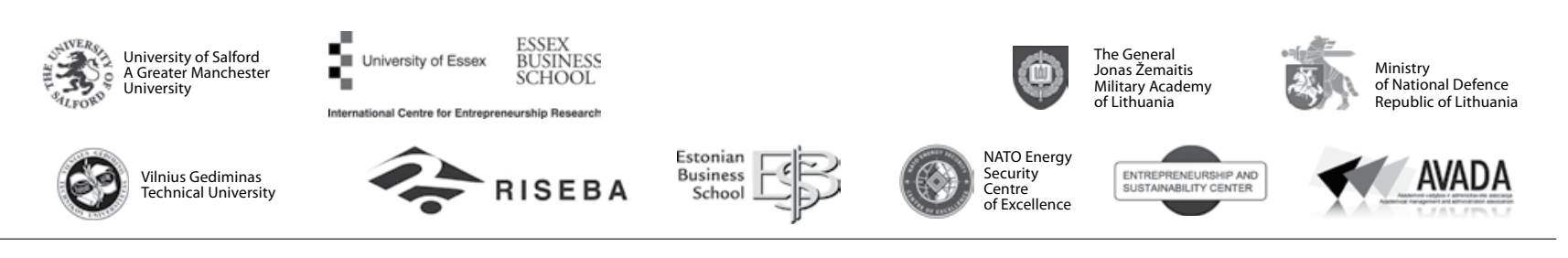

\author{
JOURNAL OF SECURITY AND SUSTAINABILITY ISSUES \\ ISSN 2029-7017 print/ISSN 2029-7025 online \\ 2017 June Volume 6 Number 4 \\ http://doi.org/10.9770/jssi.2017.6.4(8)
}

\title{
PRECONDITIONS OF FINANCIAL SAFETY DURING LIFECYCLE: THE FINANCIAL LITERACY AND RETIREMENT PLANNING IN VIETNAM
}

\author{
Thi Anh Nhu Nguyen ${ }^{1}$, Jaroslav Belás ${ }^{2}$, Jozef Habánik ${ }^{3}$, Jaroslav Schönfeld ${ }^{4}$
}

${ }^{1,2}$ Tomas Bata University in Zlin

Faculty of Management and Economics

Department of Enterprise Economics

Mostni 5139, 76001 Zlin, Czech Republic

${ }^{3}$ Alexander Dubcek University of Trencin,

Faculty of Social and Economic Relations

Studentska st. 3, 91150 Trencin, Slovakia

${ }^{4}$ University of Economics

Faculty of Business Administration

W.Churchill Sq. 4, Prague 67, 4 130, Czech Republic

Emails: ${ }^{1}$ anhnhu80@gmail.com; ${ }^{2}$ belas111@gmail.com; ${ }^{3}$ jozef.habanik@tnuni.sk; ${ }^{4}$ schonfeld@vse.cz

Received 20 November 2016; accepted 27 February 2017

\begin{abstract}
This study was performed to evaluate and examine financial literacy and retirement planning in sector employment in Vietnam in the context of financial safety during lifecycle. In order to collect primary data, a questionnaire was designed and distributed to 257 employees in the public and private sectors in Ho Chi Minh City. The results of descriptive analysis indicated that those who work in the public sector have a higher percentage of correct answers to questions about financial literacy and knowledge of social insurance than that of employees in the private sector. The results of a linear probability model (LPM) and two-stage least squares (2SLS) regression show that financial knowledge and regular saving are significant factors that enhance retirement planning, whereas sector employment is insignificant to retirement planning. These findings should improve the knowledge of financial literacy, pensions and social insurance disseminated through retirement seminars and education programs for workers. More research, however, should be conducted on these topics in Vietnam.
\end{abstract}

Keywords: financial safety, financial literacy, retirement planning

Reference to this paper should be made as follows: Nguyen; T. A. N.; Belás, J.; Habánik, J.; Schönfeld, J. 2017. Preconditions of financial safety during lifecycle: the financial literacy and retirement planning in Vietnam, Journal of Security and Sustainability Issues 6(4): 627-636. http://doi.org/10.9770/jssi.2017.6.4(8)

JEL codes: L32, D14, D91

\section{Introduction}

When people shift from one stage to another in their life cycle, they carry with them what they earned in the previous stage. Retirement is a turning point, especially with regards to managing personal and family finances. In many developed countries, retirees are supported by a large number of official programs including govern- 
ment welfare systems, private pensions, and personal savings accounts (Minh and Huu, 2016). However, in developing countries, their counterparts receive support mostly from family members or relatives, because many of them still cannot access other official financial services (World Bank 2004). In Vietnam, citizens can only access defined-benefits (DB) in the pension system. Normally, men retire at the age of 60 and women at 55, with at least 20 years of contributions. In addition, in order to increase its welfare system coverage, a voluntary insurance scheme was launched. However, its coverage rate is relatively low, and few participants take part in this scheme (OECD, 2013a). Vietnam has a population of 90 million, of which about 53 million (58\%) are in the workforce (15 - 60 years old). In $2014,21.7 \%$ of the total working population took part in the social insurance system. The majority of them work in formal sector, especially the public one (GSO, 2014).

In Vietnam, prior studies concentrating on elderly living conditions found that they still live in poverty, and other studies point out that few elderly have access to public pensions; the majority live on their families' support (Le et al., 2005; MOLISA, 2005). Moreover, over the past decade, the number of dependent elderly continuously decreased, while the number of elderly who lived on their own or with other elderly kept increasing (Giang and Pfau, 2007a). Other previous studies in Vietnam, which examined elderly people and their households, contributed data about geographic population distribution, household structure, and family relationships in regard to financial assistance (Pfau and Giang, 2007a, b). Over the same period, some studies focused on the effects of welfare benefits, household expenses, and decisive factors in poverty (Evans et al., 2007; and Tran, 2007). However, these studies do not analyze and identify possible factors that could affect how people prepare for their retirement income in the future through financial planning. In order to fill this gap, it is necessary for researchers to do more in developing countries, like Vietnam.

Accordingly, this paper examines whether the labour workforce in developing countries such as Vietnam is sufficiently financially literate to manage their social insurance benefits and properly budget for the future, especially retirement. It also looks for differences in retirement planning and financial literacy between employees in the public sector and private sector. Finally, this paper discusses the effects of financial literacy and regular saving on retirement planning.

The paper has four more parts: a literature review, a description of method and data collection, empirical results, including a statistics analysis and regression model, and then conclusions and recommendations.

\section{Literature review}

Based on economic literature on retirement planning, this literature review focuses on how people prepare for and know about their retirement and results from empirical research related to financial literacy and retirement preparation in context of developed and developing countries.

Regarding to the framework of pension system, there are two main parts in the framework of pension systems: defined benefit (DB) and defined contribution (DC). The former part is designed to make sure that pensioners can obtain some absolute, minimum standard of living. The latter part is created to attain some standard of living in retirement in comparison with that when they are at work. Hence, many private pension funds have appeared, reformed and developed in developed countries (Czech, 2016; Chovancová \& Hudcovsky, 2016; Ząbkowicz, 2016; Sika et al. 2016; Bílý, Horváthová 2016).

Besides, the importance of the media is also considered. Computer and the internet network also affect the reception and decision of consumers (Cuichi et al., 2011; Samašonok et al., 2016; Raudeliūnienè et al., 2016; Prause, 2016; Grubicka, Matuska, 2015; Štitilis et al. 2017).

However, in the previous research, Clark, et al., (2010) found that employees of five large companies have limited knowledge about their pension plan as well as Social Security. Particularly, the majority of workers do not know what kind of pension and other provisions they are engaged. In addition to this, Lusardi and Mitchell (2006, 2007a) presented evidence that older employees lack knowledge of basic financial literacy and investment to make 
important decisions in each stage in their life cycle. This shows that whether or not consumers have been equipped with sufficient financial knowledge and information to make efficient decisions in their plan for retirement.

According to literature from personal and pension finance, financial literacy plays an essential role in making informed financial decisions (van Rooij et al., 2011; Michailova et al., 2017; Njaramba et al., 2015; Kalyugina et al., 2015; Dubauskas, 2016; Bikas, Bikas, 2016).

Empirical studies into this field indicate that individuals with better knowledge of financial literacy contribute a lot to their financial well-being. This is because people good at financial literacy plan for retirement more often and there is also a positive correlation between individual's wealth and portfolio allocations in later life (Almenberg \& Dreber, 2015). In the research from 12 countries around the world, Lusardi \& Mitchell (2011a, 2014) show that the majority of people have low levels of financial knowledge and lack financial planning.

More importantly, in some remarkable findings of Lusardi \& Mitchell (2007b, 2010), part from confirming that there is the relationship between financial knowledge and plan for retirement in their future, the authors also detect the potential endogeneity problem when they assess the relationship between financial literacy and retirement planning by using OLS regression.

Regarding the areas of pension financial decision and retirement planning, so far most researches have been done in the US, and Australia (Dvorak \& Hanley, 2010; Gallery et al., 2011) where their citizens have more options to participate in retirement plans such as defined contribution (DC) besides defined benefit (DB). In addition, besides expanding conservative instruments, some empirical research also consider long term investment in stock market as a part of pension system and non - state retirement insurance system (Chovancova \& Arendas, 2015; Mykhaylo \& Kateryna, 2014). This is really different from developing world, especially Vietnam. By contrast, while a few studies are available in this field in Vietnam, they have not considered financial knowledge factor and financial behaviour yet, but mainly focus on household savings, household welfare and shelter poverty (Le, 2014; Nguyen, et al., 2015). However, in more recent years, researchers in other developing countries have started concerning about financial literacy and financial behaviors. For example, Nguyen, (2016) found that commercial banks' customers in Ho Chi Minh City in Vietnam have average level of basic financial literacy. The research in Malaysia of Mahdzan \& Tabiani (2013) addressed the relationship between financial literacy and saving by using probit regression and proved that financial literacy has a significant positive association with savings. Another research in India of Agarwal, et al., (2015) evaluated financial literacy of a group of Indian people using on-line investment services and found that consumers who have financial literacy could plan their retirement better.

\section{Methodology}

The study is based on primary data, in which 340 questionnaires were sent to employees in the public and private sectors in Ho Chi Minh City which is located at in the southeastern region of Vietnam. It is a good place to collect data because Ho Chi Minh City is the biggest city in Vietnam and the majority of companies in the public and private sectors, especially small and medium ones are located here. Particularly, data was collected from 15 companies and organizations in public sector and 28 SMEs in private sector, 5 to 10 employees from each firm or organization. The data was assembled via telephone interviews and face-to-face interviews using paper-based questionnaires, in which 257 out of 340 questionnaires were valid for data analysis, amounting to $75.58 \%$. The questionnaire consists of three main sections: (1) Basic financial literacy; (2) knowledge of pension and social insurance; and (3) demographic characteristics.

\subsection{Measure the variables}

Researcher codes dependent variables as binary variables to show whether or not an individual have a plan for their retirement $(1=$ Yes, $0=$ No). Independent variables which are coded to represent financial literacy and social insurance are each coded as a binary variable $(1=$ Correct, $0=$ Incorrect or do not know). This paper assesses financial literacy through basic financial and economic concept questions which were used in previous studies 
in many countries (Agarwal, et al., 2015; Lusardi, 2006; Lusardi \& Mitchell, 2011a). The overall measurement is based on the number of correct answers to questions. Responses could range from 0 to 3 and from 0 to 4 for financial literacy and social insurance respectively. Demographic characteristics are control variables of this study such as gender, age, and level of education, marital status, the number of children, income, and home ownership of respondents. All of them are dummy variables and they are also considered as independent variables of this study.

\subsection{Objectives and hypothesis}

Accordingly, the purpose of this paper is to find out new evidence on the case of Vietnam by considering the role of financial literacy and regular saving in retirement planning. Furthermore, we also explore how employees in the public sector and private sectors prepare for their pension plan. Therefore, the following hypotheses are proposed:

H1: Financial literacy affects retirement planning in a positive way.

H2: There is a relationship between individual regular saving and retirement planning (+/-).

$\mathrm{H} 3:$ Whether there is a correlation between retirement planning and sector employment.

\subsection{Multivariate Regression}

This research uses linear probability model (LPM) which is estimated by OLS to test hypotheses 1 to 3 . The authors also run two-stage least squares (2SLS) regression to overcome endogenous problems and avoid bias results. In 2SLS model, this research follows instrument variables proposed in previous study of Fornero and Monticone (2011). In addition, this study also uses Wu-Hausman test which is run to check endogeneity variable.

\section{Results and discussion}

\subsection{Descriptive statistics analysis}

Table 1. Participants' general demographic information

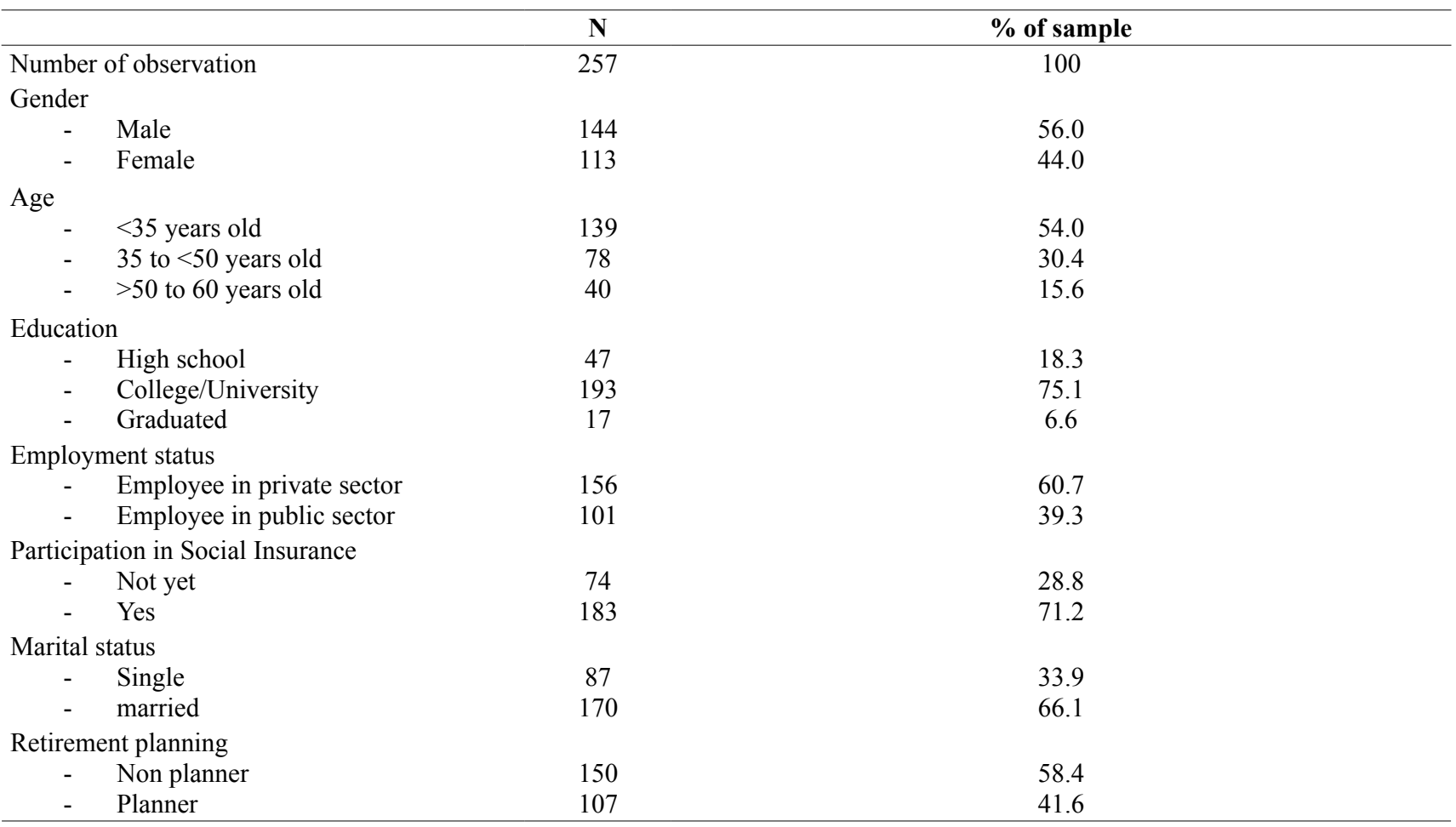


Table 1 shows general information of respondents in this research. Among 257 employees completing the survey, $60.7 \%$ of them are from the public sector and $39.3 \%$ from the private sector. The employees' level of education gained by these participants is higher than that of general population in Vietnam because those who were selected are working for private firms or government organizations or public firms belonging to the government. About $75 \%$ of them are required to hold at least a diploma or bachelor degree, $7 \%$ having post graduate degree and the remaining percentage of employees with education level of high school. 54\% of employees are under 35 years old, around $30 \%$ are from 35 to 50 age group and about $15 \%$ of employees are from over 50 to 60 years old. The percentage of employees who have participated in social insurance is around $71 \%$ and $29 \%$ has not participated yet. Finally, just over $58 \%$ of employees have planned for their retirement and the rest of this number have not planned for their retirement income. Now we move to table 2 with panels A and B, which provide information about what employees know and understand about the basic financial and economic concepts and knowledge of pension and social insurance information. In this part, this study also explores the differences in knowledge, retirement planning and social insurance contribution between employees in the public and private sectors in Vietnam.

Table 2. Distribution of responses to financial literacy and knowledge of pension and social insurance questions of employees in the public and private sectors

Panel A. financial literacy of employees in the public and private sectors

\begin{tabular}{|l|c|c|c|c|c|c|}
\hline \multirow{2}{*}{ Financial literacy } & \multicolumn{2}{c|}{ Employees in the Private sector } & \multicolumn{3}{c|}{ Employees in the Public sector } \\
\cline { 2 - 7 } & Incorrect & Do not know & Correct & Incorrect & Do not know & Correct \\
\hline Interest question & $39.70 \%$ & $14.10 \%$ & $46.20 \%$ & $37.60 \%$ & $5.90 \%$ & $56.50 \%$ \\
\hline Inflation question & $10.30 \%$ & $18.60 \%$ & $71.20 \%$ & $9.90 \%$ & $15.80 \%$ & $74.30 \%$ \\
\hline Diversification question & $18.60 \%$ & $55.10 \%$ & $26.30 \%$ & $10.90 \%$ & $52.20 \%$ & $36.60 \%$ \\
\hline Correct all 3 questions & \multicolumn{2}{|c|}{$83.30 \%$} & $16.70 \%$ & \multicolumn{2}{|c|}{$80.20 \%$} & $19.80 \%$ \\
\hline
\end{tabular}

(Source: Researcher developed based on sample survey, 2017)

Panel A of table 2 presents answers to interest compounding, inflation and risk diversification questions. It indicates that around $46 \%, 71 \%$ and $26 \%$ give a correct answer to questions related to financial literacy of employees in the private sector respectively while employees in the public sector have higher percentage of correct answers to these questions, with about $57 \%, 74 \%$ and $37 \%$. Compared with the answers on other recent research in developing countries such as India, the result of Agarwal, et al., (2015) shows Indian respondents have higher basic financial knowledge than Vietnamese employees with $81 \%, 79 \%$ and $79 \%$ correctly answering interest compounding, inflation and risk diversification questions respectively. This could be explained with two following reasons. Firstly, the respondents in that research were selected with a high level of education and secondly, those respondents took part in personal financial advice and they also used the investment online of Investment Yogi. Therefore, it would be expected that they have basic knowledge and understanding of financial and economic concepts. However, the percentage of both Vietnamese employees and Indian investors online getting a correct answer to inflation question is similar. It is easy to understand because the economy of developing world is impacted by inflation more obviously than other indicators.

Panel B. Knowledge of pension and social insurance of employees in the public and private sectors

\begin{tabular}{|l|c|c|c|c|c|c|}
\hline \multirow{2}{*}{ Social Insurance (SI) } & \multicolumn{2}{|c|}{ Employees in the Private sector } & \multicolumn{3}{c|}{ Employees in the Public sector } \\
\cline { 2 - 7 } & Incorrect & Do not know & Correct & Incorrect & Do not know & Correct \\
\hline Retired age question & $18.6 \%$ & $3.8 \%$ & $77.6 \%$ & $16.8 \%$ & $1.0 \%$ & $82.2 \%$ \\
\hline The number of yearof contribution to SI question & $46.8 \%$ & $9.0 \%$ & $44.2 \%$ & $26.7 \%$ & $3.0 \%$ & $70.3 \%$ \\
\hline The payment policy question & $29.5 \%$ & $17.9 \%$ & $52.6 \%$ & $11.9 \%$ & $7.9 \%$ & $81.0 \%$ \\
\hline Voluntary contribution to SI question & $16.7 \%$ & $23.7 \%$ & $59.6 \%$ & $2.0 \%$ & $16.8 \%$ & $81.2 \%$ \\
\hline
\end{tabular}

(Source: Researcher developed based on sample survey, 2017) 
Panel B of table 2 provides information on aggregate performance of the four questions about how employees in the public and private sectors know and understand Social insurance policies. Surprisingly, in the private sector, the result shows that over 55\% of employees do not know and answer incorrectly the question related to the number of year people have to contribute to social insurance. Similarly, nearly $50 \%$ do not know the correct answer to the question of payment policy for participators who do not take part in social insurance long enough. The last question is very important for knowledge of social insurance policy in Vietnam because according GSO, (2014) nearly $79 \%$ of the total working population did not take part in the social insurance system. Therefore, in case of employer do not buy social insurance for their employee, they can participate by them self. However, Around 40\% of employees in the private sector either do not know or understand this information improperly while more than $80 \%$ of employees in the public sector know clearly. This study discovered that most people who do not participate in social insurance are those who work for private sector and they also lack knowledge and information on social insurance compared with employees working in the public sector. This result suggests that policy makers and government should concern more about how to improve employees' knowledge of social insurance, especially those working in the private sector.

Table 3. Financial literacy of planners and non-planners

\begin{tabular}{|c|c|c|c|}
\hline & Planners & Non-planners & P-value \\
\hline \multicolumn{4}{|c|}{ Interest compounding question } \\
\hline - Correct & $84.1 \%$ & $26.0 \%$ & $<0.01$ \\
\hline - Incorrect/DK & $15.9 \%$ & $74.0 \%$ & $<0.01$ \\
\hline \multicolumn{4}{|l|}{ Inflation question } \\
\hline - Correct & $92.5 \%$ & $58.0 \%$ & \\
\hline - Incorrect/DK & $7.5 \%$ & $42.0 \%$ & \\
\hline \multicolumn{4}{|c|}{ Risk diversification question } \\
\hline - Correct & $56.1 \%$ & $12.0 \%$ & $<0.01$ \\
\hline - Incorrect/DK & $43.9 \%$ & $88.0 \%$ & $<0.01$ \\
\hline Correct all 3 questions & $41.1 \%$ & $1.3 \%$ & $<0.01$ \\
\hline $\mathrm{N}$ obs & 257 & 257 & \\
\hline
\end{tabular}

(Source: Researcher developed based on sample survey, 2017)

Table 3 shows financial knowledge of retirement planners and non-planners. The results prove that employees with higher level of financial literacy are associated with planning for their retirement $(\mathrm{P}<0.01)$. Particularly, $84 \%$ and $56.1 \%$ of employees who are planners correctly answer the interest compounding and risk diversification questions respectively while only $26 \%$ and $12 \%$ of employees who are non-planners answer these questions correctly respectively. In addition, many more planners answer correctly all 3 questions, $41.1 \%$ of planners compared with $1.3 \%$ of non-planners.

\subsection{Regression analysis}

Table 4 presents the results of regressions to assess the impact of financial literacy, knowledge of pension and social insurance and regular saving on retirement planning. The researcher uses linear probability model (LPM) which is estimated by OLS and then two-stage least squares (2SLS) regression is also exercised to overcome endogenous problems.

The result is showed in table 4. First of all, the first column shows there is a strong link between financial literacy and employees planning for their retirement. Particularly, giving one more right answer to the question on financial literacy, participants can raise their probability (36 percentage points) of retirement planning, which is akin to the result of recent studies (Boisclair et al., 2015; Lusardi and Mitchell, 2014). Likewise, employees can have a rise of 11 percentage points in probability if they save regularly. Therefore, there is a positive relationship between retirement planning and financial literacy as well as regular saving when socio-demographic personal characteristics including income, education, and home ownership, the number of the children, gender and age group are considered as control variables. Hence, the results support the first hypothesis and partly support the second hypothesis. 
However, according to the analysis of this research, results do not support the third hypothesis of this study as there is not a statistically significant relationship between retirement planning and sector employment. Although sector employment of respondents is not reliably estimated with retirement planning, the coefficients show that employees in public sector are more likely to have retirement planning than those in private sector, an increase of 7.2 percentage points in probability.

To address the endogenous financial literacy variable, researcher performs 2SLS estimation, in which a set of instrument variables are used based on a previous study of Fornero and Monticone (2011). As a result, the second column also shows a positive correlation between financial literacy and retirement planning. This finding is similar to the results of other studies (Fornero \& Monticone, 2011; Ricci \& Caratelli, 2015). In addition, the author also do Wu-Hausman test with $\mathrm{P}$-value $<0.05$, that rejects the null hypothesis as financial literacy variable is endogeneity variable. Furthermore, the $\mathrm{F}$ test is 12.9 , higher than 10 so this result could suggest that these instruments are not weak.

Table 4. Multivariate analysis of retirement planning

\begin{tabular}{|l|c|c|}
\hline & (LPM) & (2SLS) \\
\hline Financial literacy & $.362(0.02)^{* * *}$ & $.439(0.04)^{* * *}$ \\
Knowledge of Social insurance & $-.019(0.02)$ & $-.026(0.02)$ \\
Regular saving & $.117(0.05)^{* *}$ & $.091(0.04)^{*}$ \\
Participation in social insurance & $-.011(0.06)$ & $-.026(0.06)$ \\
Employees in public sector & $.072(0.05)$ & $.079(0.05)$ \\
Socio-demographic control variables & Yes & Yes \\
N obs. & 257 & 257 \\
Adj. R-Squared & & 0.53 \\
F - test & 0.55 & 12.9 \\
\hline Durbin (score) chi2(1) & 36.13 & $4.59933(\mathrm{p}=0.0320)$ \\
Wu-Hausman F $(1,237)$ & & $4.3187(\mathrm{p}=0.0388)$ \\
\hline
\end{tabular}

(Source: Researcher developed based on sample survey, 2017).

Notes: Robust standard errors in parentheses; $* * * \mathrm{p}<0.01 ; * * \mathrm{p}<0.05 ; *_{\mathrm{p}}<0.10$.

\section{Conclusions and recommendations}

\subsection{Conclusions}

This paper examines whether differences in retirement planning and level of financial literacy between employees in the public sector and private sector. Moreover, this paper also verify the effects of financial literacy and regular saving on retirement planning of sector employment in Vietnam. The researchers report some significant findings.

First, regarding to retirement planning, a big difference in financial knowledge and knowledge of pension and social insurance exists between planners and non-planners. For example, under 30\% of non-planners do not know and answer incorrectly questions about interest compounding and risk diversification while around $84 \%$ and $56 \%$ of planners answer correctly these questions respectively.

Second, in terms of sector employment, only $36.5 \%$ of employees in the private sector think about their retirement planning and this figure is quite lower than that of employees in the public sector with $50.5 \%$. Turning to knowledge of pension and social insurance, nearly a half of employees in the private sector do not take a part in social insurance and they also lack information and knowledge of pension and social insurance. Particularly, more than $40 \%$ of these employees in the private sector incorrectly answer or do not know the questions about 
payment policy of social insurance and voluntary participation in social insurance.

Finally, this paper also contributes evidence of a positive relationship between retirement planning and financial literacy as well as regular saving after controlling social demographic characteristics. The researcher also uses two instrumental variables estimation to assess causal effects of financial knowledge on retirement planning. The results also indicate that retirement planning is strongly and positively impacted by financial literacy and regular saving. Particularly, employees with financial literacy have a higher propensity to make plan for their retirement and employees doing exercise saving regularly are more likely to plan their retirement.

\subsection{Suggestions of Policy implications}

According to the results, some suggestions can be made as follows:

Firstly, government should concern about how to impart the information and knowledge of social insurance and the importance of pension income to Vietnamese people, especially those who are employees in the private sector because from the results, nearly 40 percent of them lack information and knowledge of pension and social insurance and they also do not take part in social insurance even though they can legally require their employers to buy social insurance for them.

Secondly, education system and financial institutions should think about short courses in financial education and retirement seminars for the whole community because according Duflo \& Saez, (2004) personal behavior might be influenced by the receipt of information, hence retirement seminars and financial education programs are considered an effective way to improve financial knowledge and perceive saving plan for individual retirement.

\section{Acknowledgement}

The authors are thankful to the Internal Grant Agency of FAME TBU No. IGA/FaME/2017/010: Financial Constraints on Economic Activities, for financial support to carry out this research.

\section{References}

Agarwal, S., Amromin, G., Ben-David, I., Chomsisengphet, S., \& Evanoff, D. D. (2015). Financial literacy and financial planning: Evidence from India. Journal of Housing Economics, 27, 4-21. https://doi.org/10.1016/j.jhe.2015.02.003

Almenberg, J., \& Dreber, A. (2015). Gender, stock market participation and financial literacy. Economics Letters, 137, $140-142$. https://doi.org/10.1016/j.econlet.2015.10.009

Bikas, E.; Bikas, E. (2016). Towards sustainable financial markets: impact of structured securities on portfolio management, Journal of Security and Sustainability Issues 6(2): 275-288. http://dx.doi.org/10.9770/jssi.2016.6.2(7)

Bílý, J.; Horváthová, Z. (2016). Personal security and social care: a comparison of Germany and the Czech Republic, Journal of Security and Sustainability Issues 6(1): 179-186. http://dx.doi.org/10.9770/jssi.2016.6.1(14)

Boisclair, D., Lusardi, A., \& Michaud, P.-C. (2015). Financial literacy and retirement planning in Canada. Journal of Pension Economics and Finance, 1-20. https://doi.org/10.1017/S1474747215000311

Clark, R., M. Morrill, and S. Allen. (2010) “Employer-Provided Retirement Planning Programs,” in Reorienting Retirement Risk Management, edited by R. Clark and O. Mitchell. Oxford: Oxford University Press, 2010, 36-64.

Chovancova, B., Arendas, P. (2015), Long Term Passive Investment Strategies as a Part of Pension Systems, Economics and Sociology, Vol. 8, No 3, pp. 55-67. https://doi.org/10.14254/2071-789X.2015/8-3/4

Chovancova, B., \& Hudcovsky, J. (2016). Return-risk profile of Slovak pension funds. Administratie Si Management Public, (27), 94.

Czech, S. (2016). Choice Overload Paradox and Public Policy Design. The Case of Swedish Pension System. Equilibrium. Quarterly Journal of Economics and Economic Policy, 11(3), 559-584. http://dx.doi.org/10.12775/EQUIL.2016.025

Cuichi, C., Todoran, G., Picu, D., \& others. (2011). Managing Knowledge and Data for a Better Decision in Public Administration. Administratie Si Management Public (RAMP), (17), 64-81. 
Dubauskas, G. 2016. The management of public finance literacy for sustainable economic environment, Journal of Security and Sustainability Issues 5(3): 403-409. http://dx.doi.org/10.9770/jssi.2015.5.3(8)

Duplo, E. and Saez, E. (2004). Implications of pension plan features, information, and social interactions for retirement saving decisions, in (O. Mitchell and S. Utkus, eds.), Pension Design and Structure: New Lessons from Behavioral Finance, pp. 137-53, Oxford: Oxford University Press.

Dvorak, T., \& Hanley, H. (2010). Financial literacy and the design of retirement plans. The Journal of Socio-Economics, 39(6), 645-652. https://doi.org/10.1016/j.socec.2010.06.013

Evans, M., I. Gough, S. Harkness, A. McKay, Dao, T. H., and Do, L. T. N. 2007. "The Relationship between Old Age and Poverty in Viet Nam”. United Nations Development Program (UNDP) Vietnam Policy Dialogue Paper 2007-08. Hanoi: UNDP Vietnam.

Fornero, E., \& Monticone, C. (2011). Financial literacy and pension plan participation in Italy. Journal of Pension Economics and Finance, 10(4), 547-564. https://doi.org/10.1017/S1474747211000473

Gallery, N., Newton, C., \& Palm, C. (2011). Framework for assessing financial literacy and superannuation investment choice decisions. Australasian Accounting Business \& Finance Journal, 5(2), 3.

Giang, T. L, and W. D. Pfau. 2007a. “The Elderly Population in Vietnam during Economic Transformation: An Overview.” Pp. 185-210 in Social Issues under Economic Transformation and Integration in Vietnam, Volume 1, edited by Giang T. L. and Duong K. H. Hanoi: Vietnam Development Forum.

Giang, T. L, and W. D. Pfau. 2007b. "Patterns and Determinants of Living Arrangements for the Elderly in Vietnam". Pp. 147-176 in Social Issues under Economic Transformation and Integration in Vietnam, Volume 2, edited by Giang T. L. Hanoi: The Publishing House of Social Labour.

Grubicka, J.; Matuska, E. (2015) Sustainable entrepreneurship in conditions of UN (Safety) and technological convergence, Entrepreneurship and Sustainability Issues 2(4): 188-197. http://dx.doi.org/10.9770/jesi.2015.2.4(2)

GSO. (2014). Report on labour force survey (p. 240). Vietnam: Ministry of Planning and Investment - General Statistics Office.

Kalyugina, S.; Strielkowski, W.; Ushvitsky, L.; Astachova, E. 2015. Sustainable and secure development: facet of personal financial issues, Journal of Security and Sustainability Issues 5(2): 297-304. http://dx.doi.org/10.9770/jssi.2015.5.2(14)

Le, M. S. (2014). Trade openness and household welfare within a country: A microeconomic analysis of Vietnamese households. Journal of Asian Economics, 33, 56-70. https://doi.org/10.1016/j.asieco.2014.05.005

Le, B. D, Dang, N. A, Khuat, T. H, Le, H. T, and R. L. Bach. 2005. Social Protection for the Most Needy in Vietnam. Hanoi: The World Publishing House.

Lusardi, A. (2006). Financial literacy and financial education: Review and policy implications. NFI Policy Brief, (2006-PB), 11.

Lusardi, A., \& Mitchell, O. S. (2007a). Baby Boomer retirement security: The roles of planning, financial literacy, and housing wealth. Journal of Monetary Economics, 54(1), 205-224. https://doi.org/10.1016/j.jmoneco.2006.12.001

Lusardi, A., \& Mitchelli, O. (2007b). Financial literacy and retirement preparedness: Evidence and implications for financial education. Business Economics, 42(1), 35-44.

Lusardi, A. and Mitchell, O. (2010). How ordinary consumers make complex economic decisions: financial literacy and retirement readiness. Center for Financial Studies (CFS), Working paper No. 2010, 11.

Lusardi, A. and Mitchell, O. S. (2011a). Financial literacy around the world: an overview. Journal of Pension Economics and Finance, 10(4): 497-508.

Lusardi, A. and Mitchell, O. S. (2014). The economic importance of financial literacy: theory and evidence. Journal of Economic Literature, 52(1): 5-44.

Mahdzan, N. S., \& Tabiani, S. (2013). The Impact of Financial Literacy on Individual Saving: An Exploratory Study in the Malaysian Context. Transformation in Business \& Economics, 12(1).

Michailova, J.; Mačiulis, A.; Tvaronavičienè, M. (2017). Overconfidence, risk aversion and individual financial decisions in experimental asset markets // Economic research = Ekonomska istraživanja. Pula: Taylor \& Francis. ISSN 1331-677X, 30(1): 1119-1131. http://dx.doi.org/10.1080/1331677X.2017.1311234 
Minh, N. V., Huu, N. H. (2016). The Relationship between Service Quality, Customer Satisfaction and Customer Loyalty: An Investigation in Vietnamese Retail Banking Sector. Journal of Competitiveness, Vol. 8, Issue 2, pp. 103 - 116. http://dx.doi.org/10.7441/ joc. 2016.02 .0

Ministry of Labor, War Invalids, and Social Affairs, Vietnam (MOLISA). (2005). "Mot so tinh hinh va so lieu ve nguoi cao tuoi o Vietnam" (The Current Situation and Data on the Elderly People in Vietnam), MOLISA Department of Social Protection, mimeo. Hanoi: MOLISA.

Mykhaylo, M. \& Kateryna, M. (2014). Economic and Statistical Analysis of Development of Non-state Retirement Insurance System in Ukraine, Economics \& Sociology, Vol. 7, No 2, 2014, pp. 109-122. DOI: 10.14254/2071- 789X.2014/7-2/9

Nguyen, L. D., Raabe, K., \& Grote, U. (2015). Rural-Urban Migration, Household Vulnerability, and Welfare in Vietnam. World Development, 71, 79-93. https://doi.org/10.1016/j.worlddev.2013.11.002

Nguyen, T.A.N. The Impact of Demographic Characteristics on Financial Literacy: An Empirical Study in Commercial Banks' Customers. In: European Financial System 2016: Proceedings of the 13th International Scientific Conference. Brno: Masarykova univerzita, 2016, s. 508-516.

Njaramba, J.; Chigeza, P.; Whitehouse, H. (2015). Financial literacy: the case of migrant African-Australian women entrepreneurs in the cairns region, Entrepreneurship and Sustainability Issues 3(2): 198-208. http://dx.doi.org/10.9770/jesi.2015.3.2(7)

OECD. (2013a). Pensions at a Glance Asia/Pacific 2013. OECD Publishing. Retrieved from http://www.oecd-ilibrary.org/finance-andinvestment/pensions-at-a-glance-asia-pacific-2013_pension_asia-2013-en

Prause, G. (2016). E-Residency: a business platform for Industry 4.0?, Entrepreneurship and Sustainability Issues 3(3): $216-227$. http://dx.doi.org/10.9770/jesi.2016.3.3(1)

Raudeliūnienè, J.; Stadnik, B.; Kindaryte, R. (2016). Knowledge appliance process: theoretical and practical evaluation aspects, Entrepreneurship and Sustainability Issues 3(4): 368-379. http://dx.doi.org/10.9770/jesi.2016.3.4(5)

Ricci, O., \& Caratelli, M. (2015). Financial literacy, trust and retirement planning. Journal of Pension Economics and Finance, 1-22. https://doi.org/10.1017/S1474747215000177

Samašonok, K.; Išoraitė, M.; Leškienè-Hussey, B. (2016). The internet entrepreneurship: opportunities and problems, Entrepreneurship and Sustainability Issues 3(4): 329-349. http://dx.doi.org/10.9770/jesi.2016.3.4(3)

Sika, P.; Martišková, A. (2016). Sustainability of the pension system of the Slovak Republic in the changed socio-economic conditions, Journal of Security and Sustainability Issues 6(1): 113-123. http://dx.doi.org/10.9770/jssi.2016.6.1(8)

Štitilis, D.; Pakutinskas, P.; Laurinaitis, M.; Malinauskaitè, I. (2017). A model for the national cyber security strategy. The Lithuanian case, Journal of Security and Sustainability Issues 6(3): 357-372. http://dx.doi.org/10.9770/jssi.2017.6.3(3)

Tran, D. D. 2007. "Micro-determinants of Household Welfare, Social Welfare, and Inequality in Vietnam". Pp. 151-184 in Social Issues under Economic Transformation and Integration in Vietnam, Volume 1, edited by Giang T. L. and Duong K. H. Hanoi: Vietnam Development Forum.

Van Rooij, M., Lusardi, A., \& Alessie, R. (2011). Financial literacy and stock market participation. Journal of Financial Economics, 101(2), 449-472. http://doi.org/10.1016/j.jfineco.2011.03.006

World Bank and the Consultative Group. 2004. Vietnam Development Report 2004: Poverty. Hanoi: World Bank Vietnam.

Ząbkowicz, A. (2016). A Paradox of Reforming Pensions in Poland. Equilibrium. Quarterly Journal of Economics and Economic Policy, 11(3), 585-602. DOI: http://dx.doi.org/10.12775/EQUIL.2016.026 